\title{
Common bean landraces as potential sources of resistance to anthracnose ${ }^{1}$
}

\author{
Ana Carolina da Costa Lara Fioreze ${ }^{2}$, Sibila Grigolo ${ }^{3}$, \\ Claudia Aparecida Guginski Piva ${ }^{4}$, Lays Sartori ${ }^{2}$
}

\section{ABSTRACT}

Anthracnose is an important disease caused by the Colletotrichum lindemuthianum (Sacc. \& Magnus) fungus in bean crops. It occurs throughout Brazil and may cause losses of up to $100 \%$ in grain production. About 20 genes that confer resistance to specific races of the pathogen have already been described in the literature. This study aimed to evaluate bean varieties from the Brazilian states of Santa Catarina and Paraná, regarding the resistance to anthracnose, in two cropping seasons. In addition, two commercial cultivars were used as controls: IPR Tangará, as susceptible; and BRS Campeiro, as moderately resistant. The majority of the local varieties was considered resistant or moderately resistant, being more pronounced the Amendoim cultivar, with large grains and red tegument, evincing resistance in both evaluations. Regarding this, the possibility of using them as resistance sources to anthracnose may be considered, since they also show adaptability to the environmental conditions.

KEYWORDS: Phaseolus vulgaris L.; Colletotrichum lindemuthianum (Sacc. \& Magnus); genotype x season interaction.

\section{INTRODUCTION}

Several production systems, from the most technified to the familiar ones, are adopted in bean crops and, in all of them, there is a limitation regarding production: the high incidence of diseases. One of them is anthracnose, caused by the fungus Colletotrichum lindemuthianum (Sacc. \& Magnus) (Briosi \& Cavara), affecting crops throughout Brazil and entailing losses of up to $100 \%$ in grain production.

The use of susceptible cultivars and favorable environmental conditions, especially temperatures

\begin{abstract}
RESUMO
Variedades locais de feijoeiro como fontes potenciais de resistência a antracnose

Dentre as doenças que afetam as lavouras de feijão está a antracnose, causada pelo fungo Colletotrichum lindemuthianum (Sacc. \& Magnus), com ocorrência em todo o Brasil, acarretando perdas de até $100 \%$ na produção de grãos. Cerca de 20 genes que conferem resistência a raças específicas do patógeno já foram descritos na literatura. Objetivou-se avaliar as variedades de feijoeiro dos estados de Santa Catarina e Paraná, no que diz respeito à resistência a antracnose, em duas safras. Além disso, duas cultivares comerciais foram utilizadas como controles: IPR Tangará, como suscetível; e BRS Campeiro, como moderadamente resistente. A maioria das variedades locais foi considerada resistente ou moderadamente resistente, sendo mais pronunciada a cultivar Amendoim, com grãos grandes e tegumento vermelho, evidenciando resistência em ambas as avaliações. A este respeito, a possibilidade de utilizá-las como fontes de resistência à antracnose pode ser considerada, pois, também, demonstram adaptabilidade às condições ambientais.
\end{abstract}

PALAVRAS-CHAVE: Phaseolus vulgaris L.; Colletotrichum lindemunthianum (Sacc. \& Magnus); interação genótipo x safra.

of $18-22{ }^{\circ} \mathrm{C}$ and high humidity (92-100\%) (Kimati 1980), are factors that favor the development of the disease (Rava et al. 1994). Within crops, pathogen transmissions may be caused by rainwater splashing, as it disseminates the spores that are protected by biotin (Zaumeyer \& Thomas 1957, Zambolim \& Chaves 1978).

Brazil is notably the country with the greatest pathogenic variability, with 73 races distributed in 15 states. Race 65 is remarkably frequent and widely distributed, being present in 12 states (Nunes et al. 2013), including Santa Catarina, where 11 out of 32 isolates have been identified (Gonçalves-Vidigal et al.

1. Manuscript received in Jan./2018 and accepted for publication in Jun./2018 (http://dx.doi.org/10.1590/1983-40632018v4851251).

2. Universidade Federal de Santa Catarina, Centro de Ciências Rurais, Curitibanos, SC, Brasil.E-mails: ana.lara@ufsc.br, lays_s@hotmail.com.

3. Universidade do Estado de Santa Catarina, Centro de Ciências Agroveterinárias, Departamento de Produção Vegetal, Lages, SC, Brasil.E-mail: sibilagrigolo@gmail.com.

4. Universidade do Oeste de Santa Catarina, Campos Novos, SC, Brasil.E-mail: claudia.piva@unoesc.edu.br. 
2007). Because of such a wide pathogenic diversity, breeding programs clearly make great efforts to obtain resistant genotypes.

Many genetic analyses have been conducted to study anthracnose resistance inheritance in bean genotypes, and up to 20 anthracnose resistance loci conferring resistance to specific races have been described in common bean (Ferreira et al. 2013), some of them conferring resistance to distinct races, due to the different alleles of the same gene (González et al. 2015).

A notation used to identify the different genes is the symbol base Co, as of Colletotrichum (Basset 1996). Besides the major alleles of the differentiators, some also have other resistance alleles in different genes, such as G2333, which has not only Co-42, but also Co-5 and Co-7 (Pastor-Corrales et al. 1995). There is also the allele Co-10, which occurs in the Ouro Negro cultivar, and Co-32 in the bean commercial group Dark Red Kidney. Genetic control may be monogenic, controlled by major genes, characterizing a type of vertical resistance (PastorCorrales et al. 1994). This suggests that their defense mechanism is related to the hypersensitivity reaction that occurs because of incompatibility, characterized by an oxidative reaction due to the formation of reactive oxygen species (Mehdy 1994).

The literature has reported the existence of horizontal resistance to bean anthracnose, which is conferred by a set of genes with side effects, with a quantitative effect regarding the severity of the disease; however, the effect of these genes may be masked by the effect of major genes (vertical resistance). Horizontal resistance is effective against a larger number of races and more difficult to overcome, if compared to vertical resistance (Borém \& Miranda 2005). Additionally, genotypic resistance testing should be carried out in more than one environment, especially when dealing with horizontal resistance, since the effect of the interaction genotype $\mathrm{x}$ environment may be of high magnitude and significance. In this regard, a joint variance analysis of the experiments allows verifying such facts, which are of great importance for correctly selecting superior genotypes.

As for anthracnose, according to Pereira et al. (2004), resistance sources are generally found in lines or cultivars that are not adapted to the environmental conditions of the region and with undesirable characteristics, thus being unsuitable for commercial use. In the Santa Catarina state, most of the bean production comes from small farms that use a wide variety of genotypes adapted to the local economic, environmental and social conditions, insomuch that farmers make use of the seeds produced over the years in their properties (Michels et al. 2014), what helps to maintain a wide genetic variability.

Landrace bean seeds have high rusticity and are adapted to the edaphoclimatic conditions and to the handling system adopted. A native species variety is considered a local variety where natural selection prioritizes genotypes that tolerate or resist to biotic and abiotic stresses, maintaining their production (Stella et al. 2006). The cultivation of these genotypes by small and medium farmers promotes the conservation of bean genetic resources. In view of the above, this study aimed to evaluate local bean varieties, in terms of resistance to anthracnose, in two cropping seasons.

\section{MATERIAL AND METHODS}

Thirteen local bean varieties collected in the Santa Catarina and Paraná states were evaluated for anthracnose resistance. All genotypes were donated by small and medium producers. The IPR Tangará and BRS Campeiro cultivars were used as controls, the first being susceptible and the second one moderately resistant to anthracnose. The seeds of the varieties under study were characterized according to the minimum descriptors indicated to common bean (Silva 2005) and are described in Table 1.

The genotypes were evaluated in two cropping seasons (2014/2015 and 2015/2016), at the experimental agricultural area $\left(27^{\circ} 16^{\prime \prime} \mathrm{S}, 50^{\circ} 3\right.$ "W and altitude of $1,040 \mathrm{~m}$ ) of the Universidade Federal de Santa Catarina, in Curitibanos, Santa Catarina state, Brazil, in a Haplic Cambisol and a Cfb climate.

The genotypes were sown in November (1st crop: 21 November 2014; 2nd crop: 26 November 2015), in an area under no-tillage, with canola as a predecessor crop in the winter. For basal-dressing fertilization, the formulated fertilizer 04-14-08 (N-P-K) was used at a dose of $300 \mathrm{~kg} \mathrm{ha}^{-1}$. The experimental design was randomized block, with three replicates. The experimental plot consisted of three lines of $1.0 \mathrm{~m}$ each, with spaces of $0.4 \mathrm{~m}$ among them, and 12 seeds in each line. Weed control was performed manually.

In the two seasons, bean genotypes were evaluated at $46(2014 / 2015)$ and $44(2015 / 2016)$ 
days after sowing (DAS), when the first symptoms of natural anthracnose were observed. The anthracnose severity evaluations were performed (varying in number, according to the crop) in weekly intervals, when each plant of the useful plot was rated. The evaluation considered the presence of dark-brown or brown spots on petioles and on leaf and stem veins, as well as rounded, depressed lesions light-colored in the center and delimited by a protruding black ring with a reddish-brown border on pods. A 1-9 grading scale (Pastor-Corrales \& Tu 1989) was used (1 - plant with no visible symptom, going through intermediate values up to 9 - dead plant or with a severe symptom). Data on disease severity were obtained according to the average ratings of the plants, and disease incidence data according to the classifications of plants with anthracnose symptoms in the plot. At the end of the cycle of each variety, the grain yield production of the genotypes was evaluated in $\mathrm{kg} \mathrm{ha}^{-1}$.

Table 1. Grain size and color of the varieties and cultivars evaluated for resistance to Colletotrichum lindemuthianum occurring naturally in Curitibanos, Santa Catarina state, Brazil.

\begin{tabular}{lll}
\hline \multicolumn{1}{c}{ Genotype } & \multicolumn{1}{c}{ Grain size } & \multicolumn{1}{c}{ Grain color } \\
\hline CBS 14 & Medium to large & Dark beige \\
Amendoim & Medium to large & Red \\
CBS 8 & Small to medium & Black-streaked beige \\
CBS 4 & Small to medium & Black \\
CBS 7 & Small to medium & Brown-streaked beige \\
CBS 5 & Small to medium & Black \\
CBS 12 & Small to medium & Yellow \\
CBS 3 & Small to medium & Brown-streaked beige \\
CBS 2 & Medium to large & Dark-red-streaked beige \\
CBS 13 & Small to medium & Gray \\
CBS 17 & Small to medium & Black \\
CBS 19 & Small to medium & Black \\
CBS 10 & Medium to large & White \\
IPR Tangará & Small to medium & Brown-streaked beige \\
BRS Campeiro & Small to medium & Black \\
\hline
\end{tabular}

It is worth emphasizing that diversity was observed in the cycle duration of the varieties, so the harvest took place when the pods were fully matured. For classification purposes, the varieties and cultivars rated between 1 and 3 were considered resistant, while those rated between 4 and 9 were regarded as susceptible.

The data obtained in the two cropping seasons for anthracnose severity and incidence (ratings), as well as grain yield production in $\mathrm{kg} \mathrm{ha}^{-1}$, were submitted to individual variance analysis by the $\mathrm{F}$ test $(\mathrm{p}<0.05)$, and then to a confirmation by a joint variance analysis by the $F$ test $(p<0.05)$, as well as a grouping of means by the Scott-Knott test $(\mathrm{p}<0.05)$. Inheritance coefficients were estimated for severity and incidence by individual and joint variance analyses. In addition, phenotypic correlations among the evaluated characteristics were estimated by the $t$ test at a $5 \%$ significance level.

\section{RESULTS AND DISCUSSION}

The mean squares for anthracnose severity and incidence, as well as for grain yield production, were significant for all sources of variation. The mean-square significance of the interaction genotype $\mathrm{x}$ season shows the differential behavior of the genotypes in the evaluated cropping seasons.

The mean-square significance of the interaction genotype $\mathrm{x}$ season for anthracnose severity (Table 2) was due to small differences in the mean values of the two seasons (Table 3 ). The Amendoim and CBS 17 varieties were stable, since they did not present different values for anthracnose severity in both seasons. The other genotypes, however, showed anthracnose severity with higher values in the 2014/2015 season. As for anthracnose incidence, there were similar results regarding the interaction genotype $\mathrm{x}$ environment, and the stable

Table 2. Mean squares for anthracnose severity and incidence and grain yield production in local bean varieties evaluated in the 2014/2015 and 2015/2016 seasons.

\begin{tabular}{lrcrc}
\hline \multicolumn{1}{c}{ Source of variation } & DF & Severity & Incidence & Grain yield production \\
\hline Cropping season & 1 & $86.1^{*}$ & $60,983.4^{*}$ & $19,323,480.5^{*}$ \\
Genotypes & 14 & $6.9^{*}$ & $1,713.2^{*}$ & $1,243,246.2^{*}$ \\
Genotypes x season & 14 & $3.6^{*}$ & $888.4^{*}$ & $1,386,381.8^{*}$ \\
Block & 2 & 1.8 & 371.4 & $224,362.8$ \\
Error & 56 & 0.2 & 323.4 & $335,205.3$ \\
\hline CV & & 19.2 & 30.7 & 36.9 \\
\hline
\end{tabular}

* Significant by the F test $(\mathrm{p}<0.05)$. CV: coefficient of variation; DF: degree of freedom. 
Table 3. Comparison of averages for anthracnose severity and incidence and grain yield production among local bean genotypes in two agricultural cropping seasons.

\begin{tabular}{lcrrrrr}
\hline \multirow{2}{*}{ Variety } & \multicolumn{2}{c}{ Severity } & \multicolumn{2}{c}{ Incidence $(\%)$} & \multicolumn{2}{c}{ Yield (kg ha $\left.\mathrm{a}^{-1}\right)$} \\
\cline { 2 - 7 } & $2014 / 2015$ & $2015 / 2016$ & $2014 / 2015$ & $2015 / 2016$ & $2014 / 2015$ & $2015 / 2016$ \\
\hline Amendoim & $1.5 \mathrm{Aa}^{*}$ & $1.2 \mathrm{Aa}$ & $34.6 \mathrm{Aa}$ & $21.3 \mathrm{Aa}$ & $2,206.9 \mathrm{Ab}$ & $634.3 \mathrm{Ba}$ \\
CBS 10 & $2.1 \mathrm{Ba}$ & $1.2 \mathrm{Aa}$ & $79.6 \mathrm{Bb}$ & $19.1 \mathrm{Aa}$ & $2,687.1 \mathrm{Ab}$ & $1,291.5 \mathrm{Ba}$ \\
CBS 13 & $2.7 \mathrm{Bb}$ & $1.4 \mathrm{Aa}$ & $100.0 \mathrm{Bb}$ & $43.1 \mathrm{Aa}$ & $2,414.8 \mathrm{Ab}$ & $992.8 \mathrm{Ba}$ \\
CBS 17 & $1.9 \mathrm{Aa}$ & $1.2 \mathrm{Aa}$ & $61.6 \mathrm{Ba}$ & $12.1 \mathrm{Aa}$ & $2,078.6 \mathrm{Ab}$ & $702.9 \mathrm{Ba}$ \\
CBS 19 & $3.4 \mathrm{Bb}$ & $1.3 \mathrm{Aa}$ & $55.6 \mathrm{Ba}$ & $26.3 \mathrm{Aa}$ & $2,058.3 \mathrm{Ab}$ & $1,053.1 \mathrm{Ba}$ \\
CBS 2 & $6.8 \mathrm{Be}$ & $1.9 \mathrm{Aa}$ & $100.0 \mathrm{Bb}$ & $53.9 \mathrm{Aa}$ & $809.9 \mathrm{Ac}$ & $953.2 \mathrm{Aa}$ \\
CBS 12 & $2.5 \mathrm{Ba}$ & $1.3 \mathrm{Aa}$ & $100.0 \mathrm{Bb}$ & $22.2 \mathrm{Aa}$ & $2,217.1 \mathrm{Ab}$ & $707.3 \mathrm{Ba}$ \\
CBS 7 & $2.7 \mathrm{Bb}$ & $1.3 \mathrm{Aa}$ & $100.0 \mathrm{Bb}$ & $24.9 \mathrm{Aa}$ & $1,860.4 \mathrm{Ab}$ & $1,295.7 \mathrm{Aa}$ \\
CBS 14 & $4.8 \mathrm{Bc}$ & $1.3 \mathrm{Aa}$ & $100.0 \mathrm{Bb}$ & $20.9 \mathrm{Aa}$ & $370.9 \mathrm{Ac}$ & $1,074.6 \mathrm{Aa}$ \\
CBS 3 & $5.9 \mathrm{Bd}$ & $1.7 \mathrm{Aa}$ & $100.0 \mathrm{Bb}$ & $46.7 \mathrm{Aa}$ & $1,150.9 \mathrm{Ac}$ & $1,925.9 \mathrm{Aa}$ \\
CBS 4 & $2.3 \mathrm{Ba}$ & $1.5 \mathrm{Aa}$ & $91.1 \mathrm{Bb}$ & $31.1 \mathrm{Aa}$ & $3,936.4 \mathrm{Aa}$ & $1,472.8 \mathrm{Ba}$ \\
CBS 5 & $2.7 \mathrm{Bb}$ & $1.3 \mathrm{Aa}$ & $100.0 \mathrm{Bb}$ & $26.5 \mathrm{Aa}$ & $2,696.9 \mathrm{Ab}$ & $749.9 \mathrm{Ba}$ \\
CBS 8 & $5.3 \mathrm{Bc}$ & $1.2 \mathrm{Aa}$ & $92.6 \mathrm{Bb}$ & $18.5 \mathrm{Aa}$ & $2,332.3 \mathrm{Ab}$ & $756.4 \mathrm{Ba}$ \\
IPR Tangará & $7.2 \mathrm{Be}$ & $3.7 \mathrm{Ab}$ & $100.0 \mathrm{Ab}$ & $97.9 \mathrm{Ab}$ & $754.1 \mathrm{Ac}$ & $1,278.2 \mathrm{Aa}$ \\
BRS Campeiro & $2.6 \mathrm{Bb}$ & $1.3 \mathrm{Aa}$ & $77.4 \mathrm{Bb}$ & $28.2 \mathrm{Aa}$ & $2,170.9 \mathrm{Ab}$ & $1,725.4 \mathrm{Aa}$ \\
\hline * Means followed by the same capital letter in the row and lowercase letter in the column do not differ by the Scott-Knott test (p<0.05).
\end{tabular}

* Means followed by the same capital letter in the row and lowercase letter in the column do not differ by the Scott-Knott test (p $<0.05$ ).

genotypes were the Amendoim variety and the IPR Tangará cultivar.

In the first cropping season (2014/2015), anthracnose symptoms in the genotypes were perceptible at 46 days after emergence (DAE) and, in the second season $(2015 / 2016)$, they were noticeable at 44 DAE. In both seasons, the genotype that showed the greatest severity was IPR Tangará, used as a control, considered susceptible to anthracnose (Iapar 2017). There was a wide variability in anthracnose severity among the genotypes evaluated in the $2014 / 2015$ season, forming five groups. Thus, five local varieties were inserted in the group with the lowest severity rates. According to the classification used, except for the varieties CBS 2, CBS 3, CBS 8 and CBS 14, in the 2014/2015 season, all the others were considered resistant or moderately resistant to anthracnose.

The anthracnose incidence values were different for all the varieties and cultivars between the two cropping seasons, except for the Amendoim variety and the IPR Tangará cultivar. In the first season, the genotypes showed the highest incidence values (behavior already observed for severity); whereas the IPR Tangará cultivar showed the highest incidence values in both seasons, being statistically similar to other eleven genotypes in the 2014/2015 season. Moreover, in the first season, the Amendoim, CBS 17 and CBS 19 varieties were grouped with the lowest anthracnose incidence values, differing from the other genotypes. In the 2015/2016 season, only the IPR Tangará cultivar differed from the others, in terms of incidence, with almost all its plants showing anthracnose symptoms.

The rate of diseased plants within a plant population has an important role in the understanding of the resistance/tolerance and genetic structure of the evaluated population. A higher incidence of plants with symptoms is not always related to genotypes with greater susceptibility, since severity may not show a high correlation with that one. In view of that, the incidence of diseased plants in the context of genotype characterization probably reflects the broader genetic basis of the genetic material evaluated.

Costa et al. (2016), when evaluating local red bean varieties, observed that the access BGF0013922 presented plants with resistance and susceptibility reactions to anthracnose for the pathotypes 77 and 1609 , and argued that the fact is related to the existence of genetic diversity within the same genotype and corroborated the importance of maintaining this diversity for family farming.

The genetic diversity of common bean maintained by family farms is being lost due to the replacement of local varieties by commercial cultivars (Cabral et al. 2011); hence the importance of studies that characterize local genotypes for inclusion into breeding programs. In the present study, it was possible to verify the existence of a relationship 
between anthracnose and the grain yield production of each genotype. A grain yield analysis of the evaluated genotypes is important to understand the different responses, regarding the economic damage caused by anthracnose to common bean. However, it is worth mentioning that the production of a plant is related to several other factors, such as climatic factors.

Thus, it is possible to observe that, for most of the evaluated genotypes, the highest yields were observed in the first cropping season, when anthracnose occurred in a higher degree of severity and incidence (Table 3). It is noteworthy that, among these, the anthracnose severity ratings in the first season ranged from 1.5 to 7.2. This is actually associated with the fact that the bean plants presented better conditions of growth and development in the first season, in comparison with the second one, which presented a delay in the initial development, reduced size and shorter flowering period. The genotypes CBS 2, CBS 3, CBS 7, CBS 14 and the cultivars IPR Tangará and BRS Campeiro did not show differences in yield production between the two evaluated seasons, thus considered stable for that characteristic. Most of the mentioned genotypes had severity ratings ranging from 4.8 to 7.2 , with an incidence of $100 \%$ in the first season, classifying them as moderately resistant to susceptible. It was observed that, for these genotypes, anthracnose had a negative impact on grain yield production.

The correlation between anthracnose severity and grain yield production, for the 2014/2015 cropping season, was significant and negative $(\mathrm{r}=-0.70)$ (Figure 1a), with the varieties Amendoim, CBS 10, CBS 13, CBS 17, CBS 12, CBS 7, CBS 4, CBS 5 and the BRS Campeiro cultivar considered resistant by the classification used, showing the highest yields. The IPR Tangará cultivar and the CBS 3, CBS 2 and CBS 14 varieties, however, were in the group with the greatest severity and lowest yields. As previously mentioned, anthracnose may reach losses of up to $100 \%$ of grain production under environmental conditions favorable to its development (Rava et al. 1994), and the correlation between grain yield production and ratings of anthracnose symptoms are usually negative and high (Ramalho et al. 1993). However, it is important to
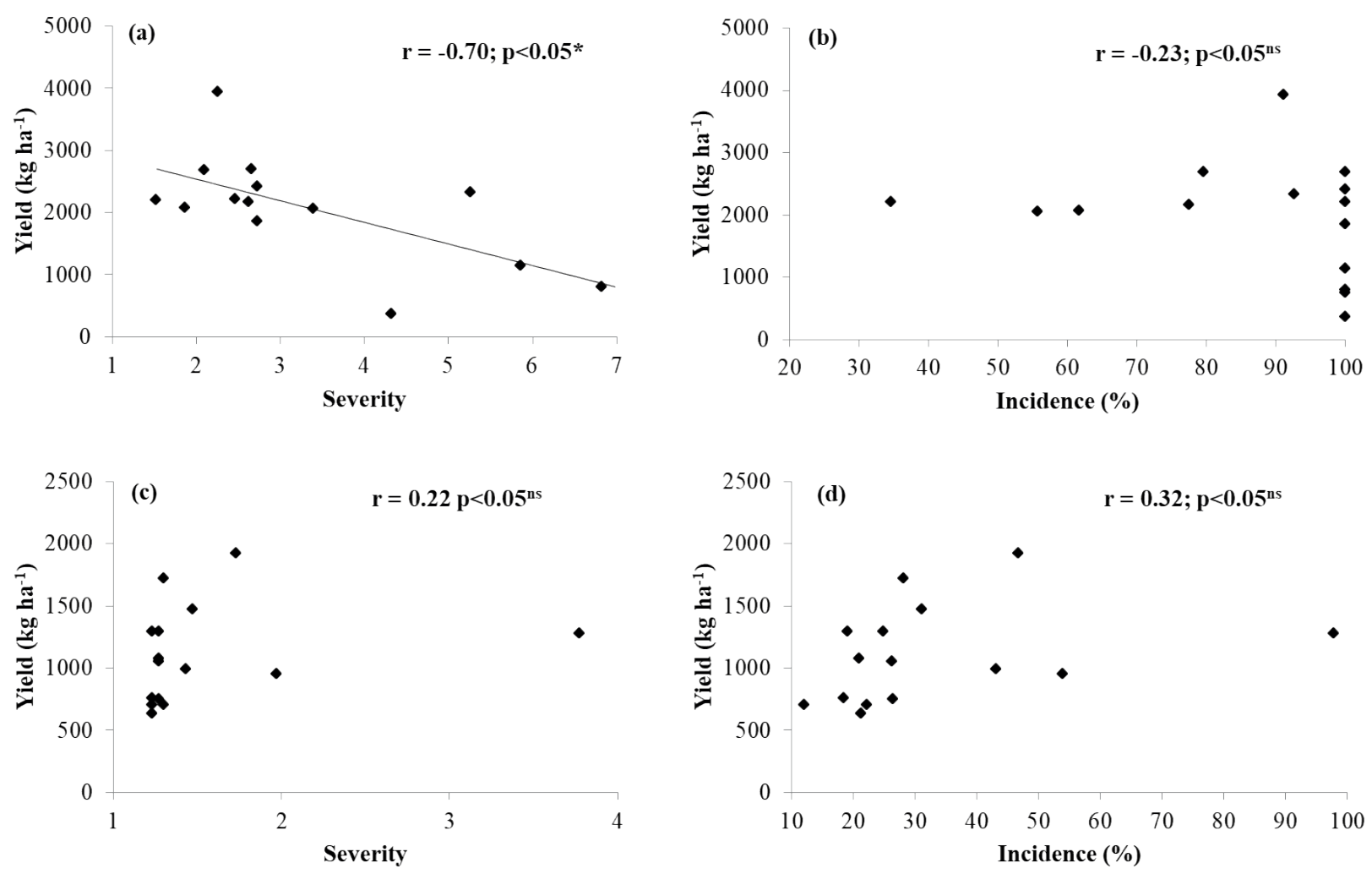

Figure 1. Pearson's correlation between anthracnose severity and grain yield production (a) and anthracnose incidence and grain yield production (b), in the 2014/2015 season; and anthracnose severity and grain yield production (c) and anthracnose incidence and grain yield production (d), in the 2015/2016 season, evaluated in local bean genotypes. 
consider the differential behavior of the genotypes, with regard to the impact of anthracnose on grain yield production.

In the second season, the correlation between incidence and yield was not significant (Figure 1b). This fact is probably associated with the lower growth and development of the genotypes that equally affected the yields (Table 3 ), and because of the lower anthracnose severity and incidence that year. The correlation between the incidence of plants with anthracnose and grain yield production was not significant in both seasons.

The rainfall levels during the evaluation period in both seasons were similar: $351.8 \mathrm{~mm}$ in the first season (2014/2015) and $344 \mathrm{~mm}$ in the second one $(2015 / 2016)$ (Epagri 2018). However, in the first season, from the beginning of the symptom to the final evaluation, it rained practically every day, and this regularity remained throughout the experiment. In the second season, however, there was no rain regularity and the highest rainfall occurred when the plants were already at the early maturation stages of the pods (R7).

Abreu et al. (2003) found low correlations between grain yield production and anthracnose incidence in most cases, nevertheless negative and significant, confirming that anthracnose is one of the causes of yield reduction in bean crops. In line with the latter authors, Singh et al. (1991) evaluated the selection efficiency in grain yield and resistance to anthracnose and angular leaf spot and found that, under a high natural occurrence of the pathogen, the susceptible genotypes were still eliminated in the seedling phase, and that the selection for resistance allowed maintaining the most productive plants in the advanced generations. In other words, in conditions of high anthracnose incidence and no other adverse factors (as in the case of the 2014/2015 season), only the genotypes with a good level of resistance to the

Table 4. Heritability coefficients $\left(\mathrm{h}^{2}\right)$ for anthracnose severity and incidence occurring naturally in thirteen local bean varieties and two commercial cultivars evaluated in two cropping seasons.

\begin{tabular}{lcc}
\hline \multirow{2}{*}{ Cropping season } & \multicolumn{2}{c}{$\mathrm{h}^{2}$} \\
\cline { 2 - 3 } & Severity & Incidence \\
\hline $2014 / 2015$ & 0.98 & 0.84 \\
$2015 / 2016$ & 0.89 & 0.67 \\
\hline Both seasons & 0.61 & 0.55 \\
\hline
\end{tabular}

pathogen will stand out for grain yield production, what reinforces the economic importance of the damage caused by $C$. lindemuthianum in common bean.

According to Abreu et al. (2003), grain yield data may be used alone or in conjunction with those disease ratings, to more effectively eliminate the families and/or strains susceptible to the pathogen. It should be emphasized, however, that, if the objective of a given program is to select fully resistant strains, only grain yield data may not be a good indication of resistance, since even those cultivars with few symptoms may not have their yields affected.

The phenotypic behavior of local cultivars and varieties reflects the sum of their genetics, the effect of the environment and the interaction between genetics and environment. For breeding programs, determining partial estimates of variance within the total variance for the characteristics of interest is of utmost importance. This way, heritability estimation is essential to guide plant breeding, aiming at gains with selection, as it reflects the genetic portion within the phenotypic portion. Heritability values for anthracnose severity were considered high in the individual analyses per cropping season (Table 4). According to Falconer (1987), when heritability values exceed $80 \%$, there is a great possibility of gains with selection. Heritability estimates for anthracnose incidence were also satisfactory, although, in the second season, the value was below $80 \%(67 \%)$. When the joint analysis of the two seasons was considered, the estimates were smaller, but more accurate, considering the interaction genotype $\mathrm{x}$ environment (Table 4). These results indicate that there is a broad genetic variability for the characteristics. According to Pádua (2013), resistance to some pathogens, among them $C$. lindemuthianum, usually presents high heritability.

The local varieties of beans evaluated certainly show a genetic variability for anthracnose resistance, for being plant populations free of selection, although allowing the maintenance of alleles of interest that may be related with genes of resistance and even with tolerance to pathogens, such as anthracnose.

\section{CONCLUSIONS}

1. Most of the studied local bean varieties were resistant or moderately resistant to anthracnose. It is worth stressing that the Amendoim variety, 
from the commercial group Dark Red Kidney bean, showed a stable behavior in both seasons evaluated. The CBS 2 variety, from the commercial group Cranberry, showed a behavior similar to that of the IPR Tangará cultivar, a susceptible control;

2. In view of the diversity of grain types, as regards the tegument size and color, and especially the adaptability to the environmental conditions, the local bean varieties investigated here may be exploited as sources of anthracnose resistance in breeding programs.

\section{REFERENCES}

ABREU, A. F. B. et al. Utilização da produtividade de grãos na seleção para resistência ao Colletotrichum lindemuthianum no feijoeiro. Ciência e Agrotecnologia, v. 27, n. 2, p. 363-369, 2003.

BASSET, M. J. List of genes: Phaseolus vulgaris L. Annual Report of the Bean Improvement Cooperative, v. 39, n. 1, p. 1-19, 1996.

BORÉM, A.; MIRANDA, G. V. Melhoramento de plantas. 4. ed. Viçosa: Ed. UFV, 2005.

CABRAL, P. D. S. et al. Diversidade genética de acessos de feijão comum por caracteres agronômicos. Revista Ciência Agronômica, v. 42, n. 4, p. 898-905, 2011.

COSTA, J. G. C. et al. Reação à antracnose de variedades tradicionais de feijão-comum com grãos do tipo comercial vermelho. Santo Antônio de Goiás: Embrapa Arroz e Feijão, 2016.

EMPRESA DE PESQUISA AGROPECUÁRIA E EXTENSÃO RURAL DE SANTA CATARINA(Epagri). Centro de Informações de Recursos Ambientais e de Hidrometeorologia de Santa Catarina. Boletim 2018. Available at: $<$ http://agriculturaconservacionista.ufsc.br/ $>$. Access on: 20 Jan. 2018.

FALCONER, O. S. Introdução à genética quantitativa. Viçosa: Ed. UFV, 1987.

FERREIRA, J. J. et al. Organization of genes conferring resistance to anthracnose in common bean. In: VARSHNEY, R.; TUBEROSA, R. (Eds.). Translational genomic for crop breeding: abiotic stress, yield and quality. New Jersey: John Wiley \& Sons, 2013. p. 151-182.

GONÇALVES-VIDIGAL, M. C. et al. Allelic relationships of anthracnose (Colletotrichum lindemuthianum) resistance in the common bean (Phaseolus vulgaris L.) cultivar Michelite and the proposal of a new anthracnose resistance gene, Co-11. Genetics and Molecular Biology, v. 30, n. 3, p. 589-593, 2007.
GONZÁLEZ, A. N. et al. Uncovering the genetic architecture of Colletrotrichum lindemuthianum resistance through QTL mapping and epistatic interaction analysis in common bean. Frontiers in Plant Science, v. 6, n. 1, p. 1-13, 2015.

INSTITUTO AGRONÔMINO DO PARANÁ (Iapar). Principais características das cultivares de feijão com sementes disponíveis no mercado. 2017. Available at: $<$ http://www.iapar.br/pagina-1363.html > . Access on: 03 Jan. 2018.

KIMATI, H. Doenças de feijoeiro Phaseolus vulgaris L. In: GALLI, F. (Ed.). Manual de fitopatologia: doenças das plantas cultivadas. São Paulo: Agronômica Ceres, 1980. p. 297-318.

MEHDY, M. C. Active oxygen species in plant defense against pathogens. Plant Physiology, v. 105, n. 2, p. 467472, 1994.

MICHELS, A. F. et al. Qualidade fisiológica de sementes de feijão crioulo produzidas no oeste e planalto catarinense. Revista Ciência Agronômica, v. 45, n. 3, p. 620-632, 2014.

NUNES, M. P. et al. Comprehension of genetic variability and virulence of Colletotrichum lindemuthianum in common bean. In: BIENNIAL MEETING OF THE BEAN IMPROVEMENT COOPERATIVE, 51., 2013, Portland. Program and Abstracts... Prosser: BIC, 2013. p. 13.

PÁDUA, J. M. V. Implicações da seleção precoce para a resistência à antracnose no melhoramento genético do feijoeiro. 2013. 73 f. Dissertação (Mestrado em Genética e Melhoramento de Plantas) - Universidade Federal de Lavras, Lavras, 2013.

PASTOR-CORRALES, M. A. et al. Inheritance of anthracnose in common bean accession G2333. Plant Disease, v. 78, n. 1, p. 959-962, 1994.

PASTOR-CORRALES, M. A. et al. Resistance to Colletotrichum lindemuthianum isolates from middle America and Andean South America in different common bean races. Plant Disease, v. 79, n. 1, p. 63-67, 1995.

PASTOR-CORRALES, M. A.; TU, J. C. Anthracnose. In: SCHWARTZ, H. F.; PASTOR-CORRALES, M. A. (Eds.). Bean production problems in the tropics. Cali: CIAT, 1989. p. 77-104.

PEREIRA, H. S.; SANTOS, J. B.; ABREU, A. F. B. Linhagens de feijoeiro com resistência à antracnose selecionadas quanto a características agronômicas desejáveis. Pesquisa Agropecuária Brasileira, v. 39, n. 3, p. 209-215, 2004.

RAMALHO, M. A. P. et al. Melhoramento visando à obtenção de cultivares de feijão resistentes à antracnose. In: REUNIÃO NACIONAL DE PESQUISA DE FEIJÃO, 4., 1993, Londrina. Resumos... Londrina: Iapar, 1993. p. 111. 
RAVA, C. A.; PURChIO, A. F.; SARTORATO, A. Caracterização de patótipos de Colletotrichum lindemuthianum que ocorrem em algumas regiões produtoras de feijoeiro comum. Fitopatologia Brasileira, v. 19, n. 2, p. 167-172, 1994.

SILVA, H. T. Descritores mínimos indicados para caracterizar cultivares/variedades de feijão comum (Phaseolus vulgaris L.). Santo Antônio de Goiás: Embrapa Arroz e Feijão, 2005. (Documento, 184).

SINGH, S. P. et al. Independent, alternate, and simultaneous selection for resistance to anthracnose and angular leaf spot and effects on seed yield in common bean (Phaseolus vulgaris L.). Plant Breeding, v. 106, n. 4, p. 312-318, 1991.

STELlA, A. et al. Políticas públicas para a agrobiodiversidade. In: STELLA, A.; KAGEYAMA, P. (Coords.). Agrobiodiversidade e diversidade cultural. Brasília, DF: MMA, 2006. p. 41-56.

ZAMBOLIM, L.; CHAVES, G. Doenças do feijoeiro e seu controle. Informe Agropecuário, v. 4, n. 1, p. 50-63, 1978.

ZAUMEYER, W. J.; THOMAS, H. R. A monographic study of bean diseases and methods of their control. Washington, DC: USDA, 1957. (Technical bulletin, 868). 